\title{
Climate Change Is not Only GHGs but Also Economics
}

\author{
Jan-Erik Lane \\ Correspondence: Jan-Erik Lane, professor emeritus at UNIGE, Geneva, Switzerland
}

Received: August 28, 2018

doi:10.11114/aef.v5i6.3655

\author{
Accepted: September 18, $2018 \quad$ Available online: September 25, 2018 \\ URL: https://doi.org/10.11114/aef.v5i6.3655
}

\begin{abstract}
Climate and Earth scientists have recently provided compelling evidence for abrupt climate change, but this amount to only $50 \%$ of this drama. We must ask: If GHGs threaten human survival, why do not humans alter the system of economic production, especially the energy supply responsible for the accelerating global warming? The question of how to transform energy consumption is little discussed: tools, mechanisms, global coordination, country resilience, state or market? Actually, the resistance to energy change is very strong,
\end{abstract}

Keywords: economics of climate change, Stern, abrupt climate change, energy-human capabilities

\section{Introduction}

The new theory of abrupt climate change, speaking of the risk of tipping points conducive irreversible global warming a "hotspot Earth", is based on the model of a game against Nature from game theory. The future would hold two states: survival versus extinction for humanity. And two policy responses would cover on the one hand global coordination and country resilience on the other hand. Thus we have:

DIAGRAM 1. Climate change as a game against Nature

\begin{tabular}{|c|c|c|}
\hline \multicolumn{3}{|c|}{ NATURE } \\
\hline & Human Survival & Human Extinction \\
\hline Global & & \\
\hline Coordination & $\mathrm{A}=\mathrm{P} 1 \mathrm{XU} 1$ & $\mathrm{~B}=\mathrm{P} 2 \mathrm{XU} 2$ \\
\hline \multicolumn{3}{|l|}{ Policy } \\
\hline \multicolumn{3}{|l|}{ Response } \\
\hline Country & $\mathrm{C}=\mathrm{P} 3 \mathrm{XU} 3$ & $\mathrm{D}=\mathrm{P} 4 \mathrm{XU} 4$ \\
\hline Resilience & & \\
\hline
\end{tabular}

The COP21 Treaty is hopefully an example of A, but the probability of success is very uncertain, as B is still possible depending on how COP21 is implemented up to 2030. Countries like for instance the USA may opt for resilience, C, hoping it can develop own measures against the downplayed consequences of global warming. However, the likely outcome of country resilience is $\mathrm{D}$, it seems according to several climate and earth scientists.

\section{Holoscene, Anthropocene and Nature's Revenge: Less Degrees of Freedom}

Social action, interaction as well as social system build upon the degrees of freedom that the environment, DNAs and the Universe provide humans with. These degrees of freedom were increased during the industrial revolution up to now. In the recent inquiry into climate change, "Trajectories of the Earth System in the Anthropocene", the hope of distinguished authors is tied to halting climate change. Despite dire warning about the future dismal state of Planet Earth threatening human survival, the authors state that the COP21 promises may save mankind, as long as they restrict global warming to +2 degrees Celsius. I quote:

"The beginning of the industrial revolution around the late 18th century is sometimes proposed as a start date for the Anthropocene .... Its importance as the beginning of large-scale use by humans of a new, powerful, plentiful energy source - fossil fuels - is unquestioned. Its imprint on the Earth System is significant and clearly visible on a global scale. 
However, while its trace will remain in geological records, the evidence of large-scale shifts in Earth System functioning prior to 1950 is weak. Of all the candidates for a start date for the Anthropocene, the beginning of the Great Acceleration is by far the most convincing from an Earth System science perspective. It is only beyond the mid20th century that there is clear evidence for fundamental shifts in the state and functioning of the Earth System that are (1) beyond the range of variability of the Holocene, and (2) driven by human activities and not by natural variability." (David, 2018:

Yet, the Anthropocene period is coming to its end, as Nature's revenge works itself out in the ferocious positive feedback loops of global warming - the so- called tipping-points. Typical of today's realities is the accelerating helplessness of governments and state towards the tipping-points and their consequences threating to make Planet Earth a hot spot with much less land for humans. Thus, the degrees of freedom are shrinking.

I quote this much discussed report again:

"...greenhouse gases are still rising rapidly, threatening the stability of the climate system, and tropical forest and woodland loss remains high. The pursuit of growth in the global economy continues, but responsibility for its impacts on the Earth System has not been taken. Planetary stewardship has yet to emerge. Will the next 50 years bring the Great Decoupling or the Great Collapse? The latest 10 years of the Great Acceleration graphs show signs of both but cannot distinguish between these scenarios, or other possibilities." (David, 2018:

If GHGs are such a formidable threat to human survival (50\% of the story), what is that drives forth this abrupt climate change with its positive feedback? Reply: Energy demand and supply, meaning economics (50\% of the story).

\section{The Industrial Revolution: Progress and Energy}

The idea of progress was born with coming of the many innovations during the $18^{\text {th }}$ and $19^{\text {th }}$ centuries. Perhaps Scottish enlightenment played a crucial role for the thought that human life and the social systems of men and women could be improved year in and year out, endlessly. "Paradise" could be accomplished here on Earth promised the new ideologies, replacing religion, when industry and urban dwellings started to replace agriculture and rurality.

The confidence in machines was boundless, as with Karl Marx. Yet, they needed the new form of energy, namely fossil fuels first coal, then oil and finally now massive amounts of natural gas. As the industrial revolution took the form of the adoption of the institutions of modern capitalism, early warnings about tensions between profitability and environmental sustainability were launched, by Marxists and egologists.

Yet, the greenhouse effect from the emission of $\mathrm{CO} 2 \mathrm{~s}$ was first formulated in a succinct manner by Swedish chemist Arrhenius around 1900, though already French mathematician Fourier anticipated the insight. Not until the 1990 was there a general recognition that fossil fuel consumption would lead to global warming on a scale that threatened humanity.

The insights of people like Keeling, Sawyer, Schneider and Hansen inter alia run against mainstream economic theory after 1945, emphasizing the necessity of economic growth for human progress. Of particular importance was the notion of "take-off", launched by Rostov in 1960. To raise affluence, countries must experience the time point when capitalist developments take off spontaneously. In Asia, state led measures attempted to simulate the take-off point. National income would start growing in combination with urbanization and industrialization, lifting millions out of poverty. Global economic growth would provide all nations in the market economy with a decent level of human development, or a set of human capacities. The so-called Washington Consensus underlined economic freedom and liberalization of trade and investments. The sooner the take-off, the more likely there would occur catch-up by the Third World. But all of this required one thing, cheap energy.

In rich countries with an economy in balance more or less, domestically and internationally, the Baptiste Say perspective upon economic motivation entails the idea of balanced economic growth, supported strongly by financial markets. Even if real economic growth fluctuates, the emphasis upon yearly economic growth is typical of modern capitalism or the market economy, but so far it has necessitated a constant augmentation of energy. Figure 1 shows the tight relation between affluence and energy consumption. 


\section{LN (Primary Energy Consumption /J)}

\section{GDP - Energy consumption World 1980 - 2017}

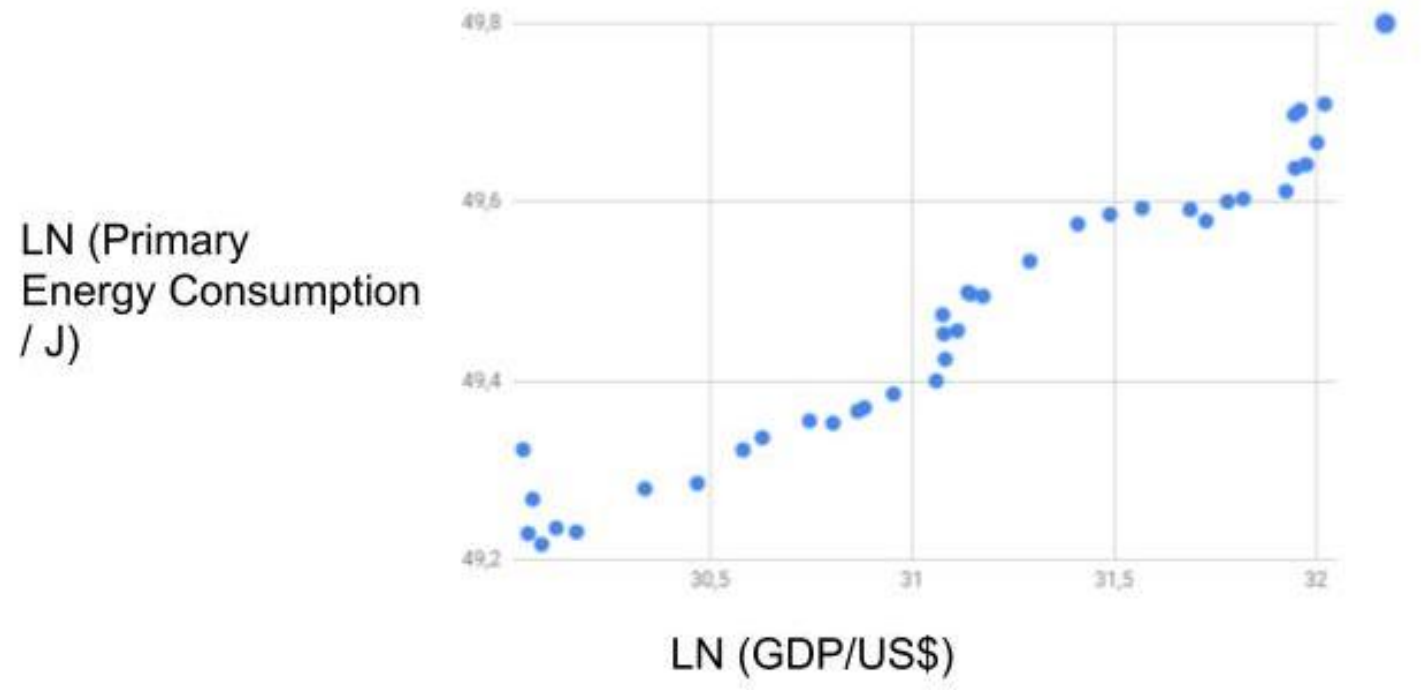

Figure 1. Affuence and energy globally

Note: $\mathrm{R} 2=0.951$

Sources: BP Statistical Review of World Energy

World Bank Data Indicators

The enormous demand for more and more of energy comes with a major drawback, namely the GHG emissions. Figure 2 has the picture for the carbon intensity of energy, resulting in $\mathrm{CO} 2 \mathrm{~s}$.

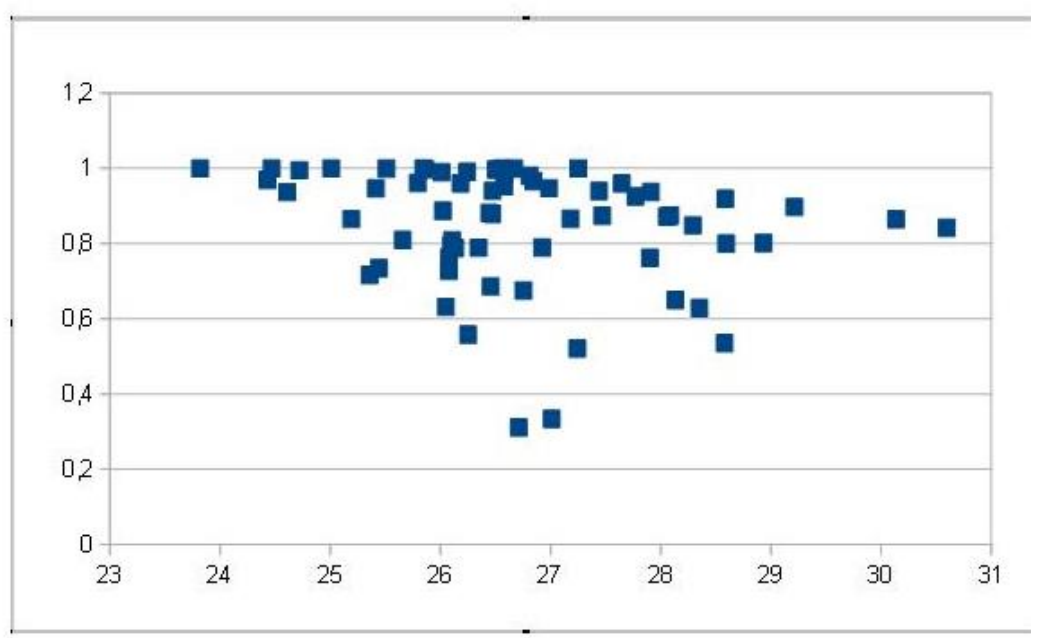

Figure 2. Carbon intensity of energy (fossil fuels/all energy)

Very few countries score under 50 per cent: Norway and Sweden as well as South Africa, but several countries score $100 \%$ or close: The Gulf States, Algeria, former Soviet Union states ("Stans"), Turkey, Mexico, etc.

This enormous expansion of energy supply of fossil fuels has made part of the world's nations rich. They want to hold on to this progress and even deepen it. And the poor countries are driven by the ambition to "catch-up" when they have managed to "take-off". Energy is key in this strategy, also using fossil fuels.

\section{Energy and the Third World}

Most people on Planet Earth lives in poor or developing countries. Their life chances depend upon access to cheap energy. One may relate the standard indicators in the UN developmental index to energy access in order understand the claim of the Third World that COP21 suggested decarbonisation must not lead to a new energy shortage. 
Figure 3 displays how environment hazards decline with energy supply. This is country resilience with other words against inundation, storms, etc.

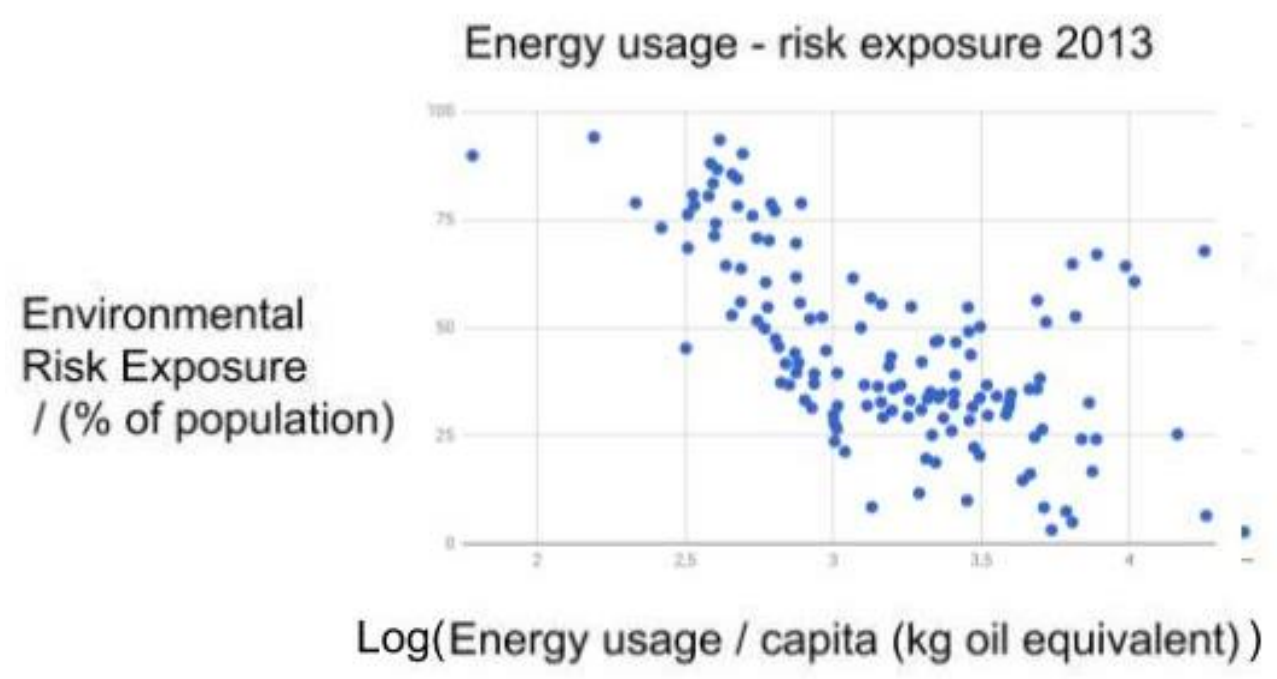

Figure 3. Energy and environmental risk exposure

Source: Environmental Performance Index, Yale University, https://epi.envirocenter.yale.

IEA Statistics (C) OECD/IEA 2014 (http://www.iea.org/stats/inde

Low energy use leads to poverty, malnutrition, deceases, lack of potable water, insufficient sanitation, etc. Typical of many Latin American, African and Asian nations is the lack of stable electricity, which hampers everything and reduces environmental viability. Figure 4 has the global picture about the necessity of more energy supply..

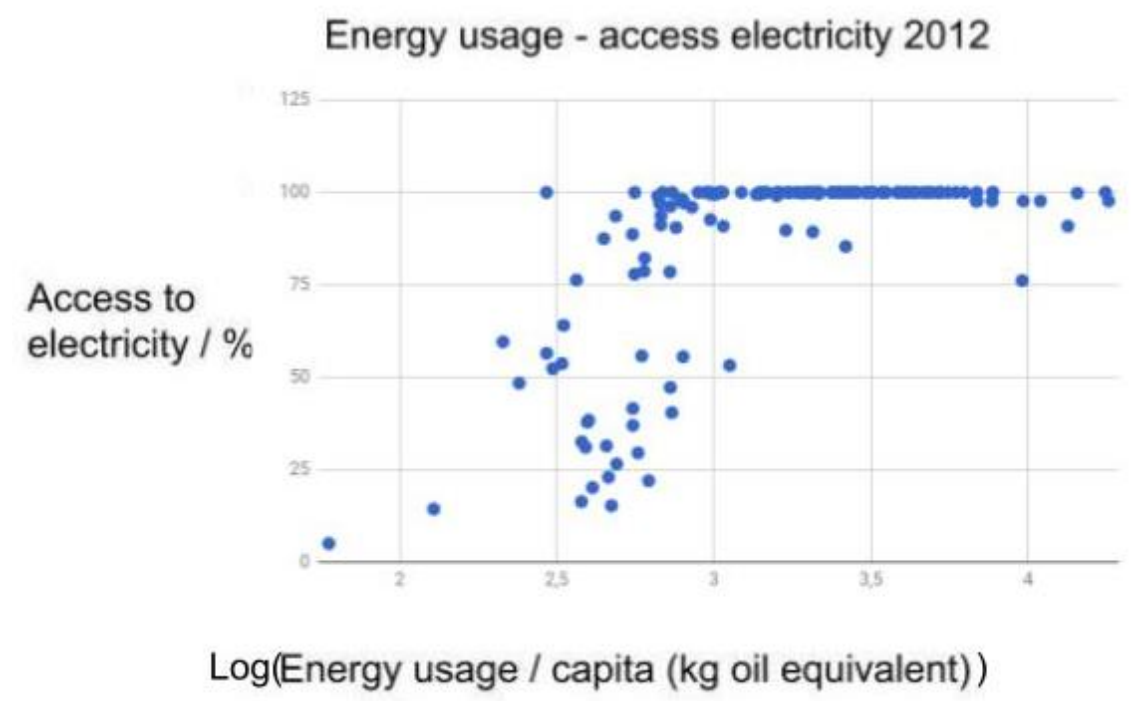

Figure 4. Energy and electricity access

Source: Environmental Performance Index, Yale University, https://epi.envirocenter.yale.

IEA Statistics @ OECD/IEA 2014 (http://www.iea.org/stats/inde

The access to safe and stable electricity is crucial for health, schools, food, water, etc. Figure 4 links energy with proper sanitation. Especially, the rapidly growing African, Latn American and Asian mega-cities lack entirely proper sewage plants. Thus, dirty water is put into the big rivers where other cities downstream take their potable water. Figure 5 links energy with proper sanitation. 


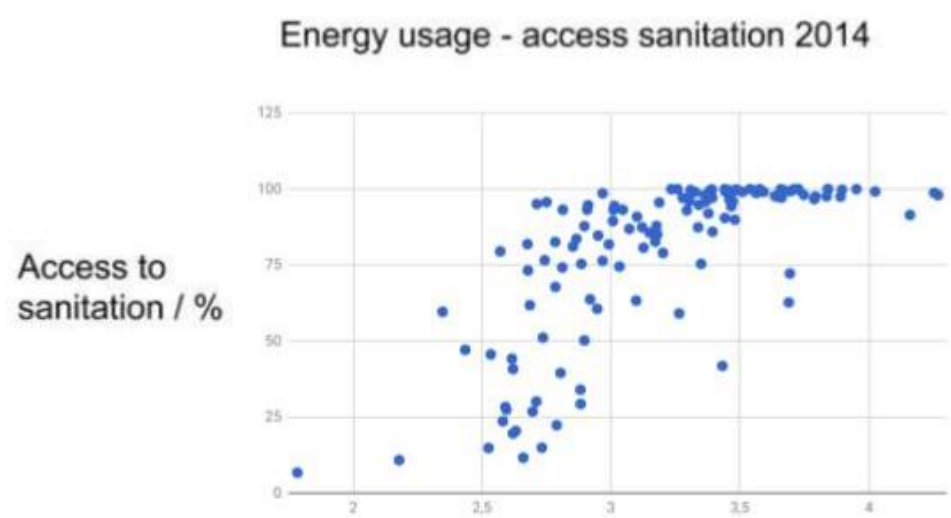

Log(Energy usage / capita ( $\mathrm{kg}$ oil equivalent))

Figure 5. Sanitation and energy

Source: Environmental Performance Index, Yale University, https://epi.envirocenter.yale.

IEA Statistics @ OECD/IEA 2014 (http://www.iea.org/stats/inde)

Figure 6 underscores the necessity of more energy for proper sanitation, without which the life of humans is "salle".

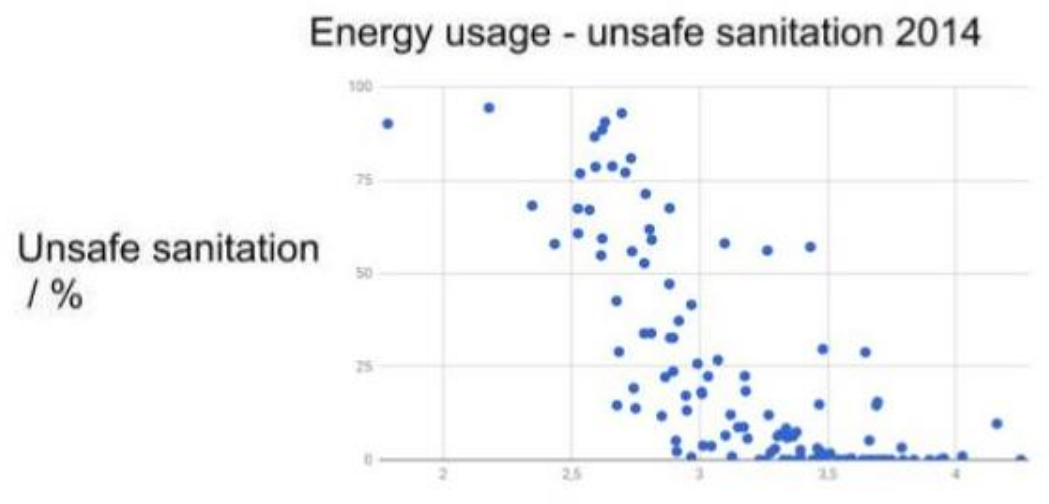

\section{Log(Energy usage / capita ( $\mathrm{kg}$ oil equivalent))}

Figure 6. Energy and unsafe sanitation

Source: Environmental Performance Index, Yale University, https://epi.envirocenter.yale.

IEA Statistics @ OECD/IEA 2014 (http://www.iea.org/stats/inde)

Air quality too depends upon energy access (Figure 7).

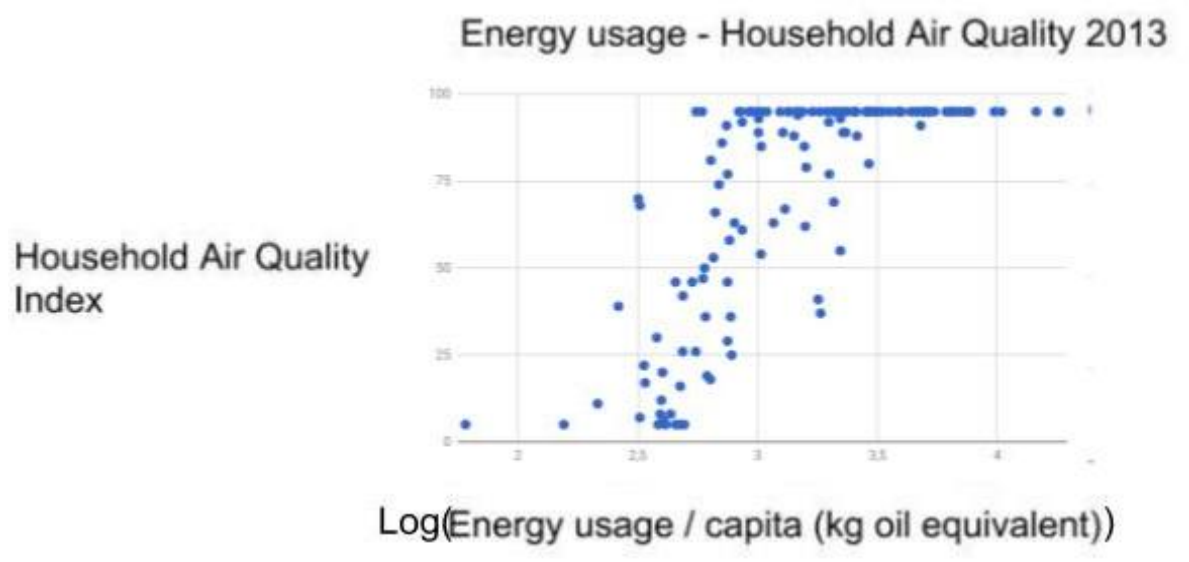

Figure 7. Energy and air quality 
Source: Environmental Performance Index, Yale University, https://epi.envirocenter.yale.

IEA Statistics @ O OECD/IEA 2014 (http://www.iea.org/stats/inde)

Bad or dangerou air to breed is found in most big Third World cities. Againt intolerable heat, the use of air conditioners has spread around globe, requiring electricity. It is a positive feedback, increasing GHGs.

Water

The most essential ingredient in human life situation is access to potable water, for drinking and for food production. Yet, energy shows up here too - see Figures. Without water, mass starvation.

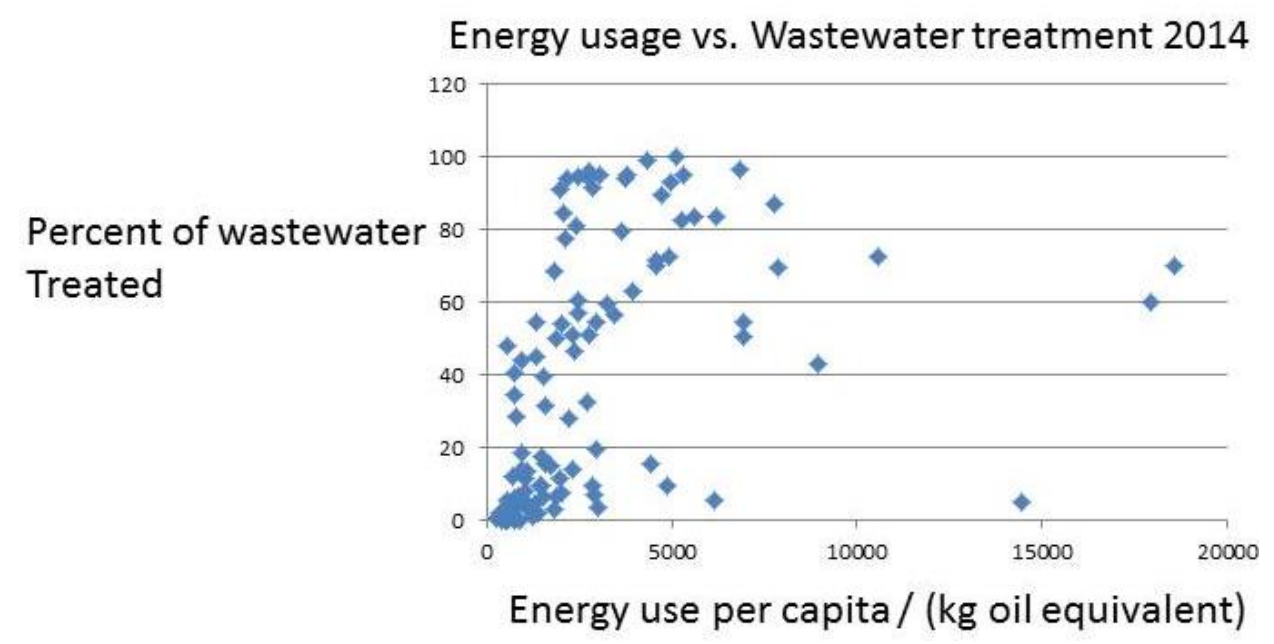

Figure 8. Water I

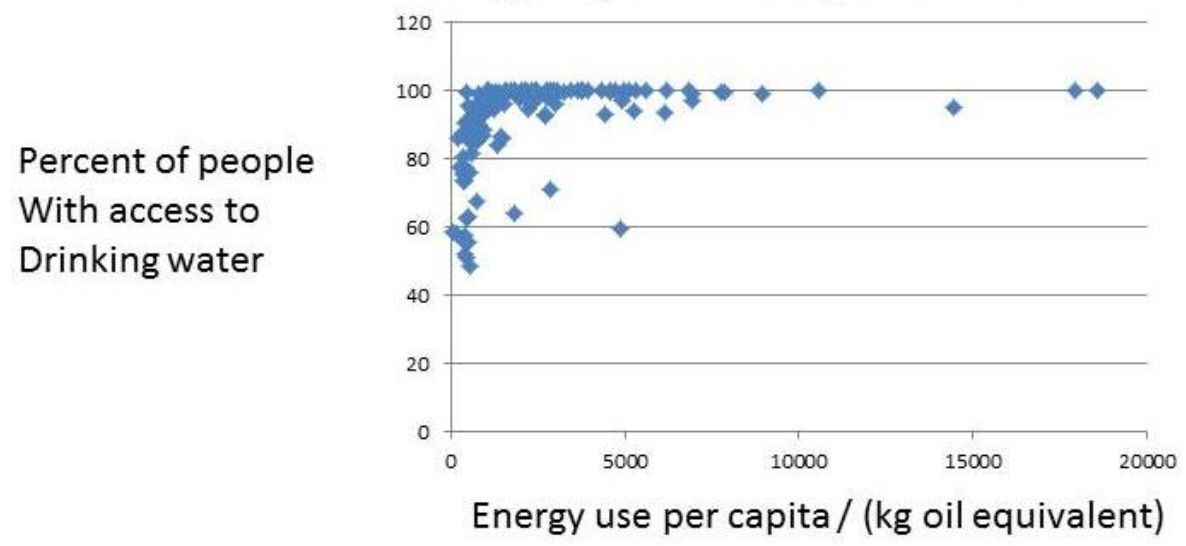

Energy usage vs. Drinking Water Access 2014

Figure 9. WATER II

To Sum Up: Energy consumption crops up everywhere in processes of economic growth in rich countries and socio-economic development in poor nations. If decarbonisation is not to lead to economic retrogression, then lots of investments and innovations are necessary, and time is tight. One understand Ramesh (2015) saying that India can only accept COP21 decarbonisation, if its energy demand is somehow satisfied, meaning billions of support for enery transition to keep socio-economic development on track.

\section{What Strategies of Decarbonisation Are Realistic Economically Speaking?}

As the basic cause of global warming is the GHGs, an energy transformation from fossil fuels to renewables or nuclear power is necessary. But how to transform the global economy? Since the CO2s remain for hundreds of years in the atmosphere, decarbonistion must entail complete elimination of coal, oil and natural gas. It could be done by forbidding the economy to employ fossil fuels, with mass unemployment and economic depression as consequence, albeit only a theoretical possibility.

Take the air transportation industry as an example. The increasing airline industry pollutes like the giant polluter countries, but a shut-down would make millions unemployed. The same holds for ocean and sea transportation. 
Conceivable, one faces the following alternatives to conduct decarbonisation:

\section{A. Laissez-Aller:}

Even though 193 governments agreed to the Paris COP21 Accord, it remains today much business as usual. Will its tempo of decarbonisation be followed and will it be enough to stall climate change. Very uncertain. It is true that several countries conduct various decarbonisation plans, but it is hardly coherent policy. Thus, some countries close nuclear power plants, others build giant dams despite water shortages and several plan for new mega projects that require much more energy. CO2s have still not leveled off. A few countries bet on natural gas like the US and South Korea. Coal has been reduced but far from eliminated. The airline industry keeps growing.

\section{B. Global Coordination:}

The CO withP21 Treaty is what will start from 2020 in a slow pace, ending in 2075 with "complete" decarbonisation.The COP Treaty also falls under the model of a common pool regime (CPR). CPRs are based upon promises among a group of actors or players concerning the regulation of the use of a common resource, typically in scarce supply. According to Ostrom' analysis (1990), CPRs rely upon self-policing. She focussed upon domestic CPRs mainly, and downplayed too much the indirect role of the state. But we find CPRs in international relations, where there is no third party Umpire who can play the role of Hobbes' illuminating judge, enforcing contracts or promises:

"Covenants, without the sword, are but words and of no strength to secure a man at all."

Now, will the COP21 work as the CPR that saves mankind? Or will governments abstain from opportunistic behaviour, reneging upon their promises? Probably NOT. Why? Because the value of the game is tremendously important, namely energy. Hawking irreversibility is practically sure, as massive decarbonisation is highly improbable. Some government will defect upon COP21 as a PD game (Dutta, 1999);

\section{Country Resilience:}

Countries may trust their own capacity to face the consequences of climate change, or underestimate the force of what will come, like the US. Yet, resilience may work for big countries with many resources. Most countries have little resilience and much rely upon global coordination.

Several countries engage in precaution, protecting itself against sea level rise, forest fires, rain storms with flooding and mud and land-slides. Some also cut back fossil fuels, or promise to so do more than committed in the COP21 approach. There are carbon taxes and markets for emission rights in a few countries.

But the CO2s keep increasing for 2017 and 2018. In addition, there is methane bomb. The objective of plus 2 degrees Celsius is opaque, as Planet Earth is heading for more and even plus 1 degree Celsius could be lethal due to the enormous positive feedback lopes released now.

Building levies, drilling deeper ever for potable water, building desaliensation plants and promoting renewables would be much more effective, if there were a global coordination plan, like the COP21 Agreement. But this stumbles upon the ocean PD game inherent in all coordination of this type.

\section{Cooperation or Defection in Ocean Games or Ocean Clubs}

The COP21 Treaty, or any other similar agreement, would have two parts: i) reduction of $\mathrm{CO} 2$ emissions ina certain pace towards zero emissions at some future date; ii) contributions to the Super Fund yearly according to some scheme and time table.

Both these two actions concern first and foremost the countries in the G20 group of nations, responsible for 70 per cent of the total $\mathrm{CO} 2$ emissions. Small poor nations can be left beside, as they pollute little and cannot be required to pay into the Super Fund.

Both i) and ii) are just promises, which the COP21 Secretariat or the UN cannot enforce, strictly speaking. When a country receives support the Super Fund, there is some leverage to force obedience. However, a big poor country may simply refuse decarbonisation, if no assistance is provided.

Decarbonisation is costly in the short run for all countries, as the must replace existing energy plants with new, hopefully renewable energy resources. Contriuting to the Super Fund is also costly in the short run. This sets up an interaction where a government may be tempted to defect from its promises to decarbonise or pay to the Super Fund.

A. Stratey of poor nations: the N-1 problematic. Poor or small nations will engage in opportunism with guile in order to avoid too large costs with the COP21 decarbonisation policy, pretending they matter very little for outcomes.

B. Strategy of the rich country: the $1 / \mathrm{N}$ problematic. Large or rich countries will find sacrifices that cannot be internalised as meaningless gifts to others, who may not be trusted to cooperate. Thus, the US reneged because it did not want to pay for decarbonisation in India. 


\section{Demand And Supply of Energy}

Climate and Earth scientists have informed daily about the severe positive feedback from global warming. They point out that the cause if the emission of GHGs, especially, which must be halted and decreased quickly. Yet, the rooy cause of the climate change drama is the constantly increasing thurst for energy in the social systems of human beings. Though the rise in energy supply has been phenomenal during the recent twenty years, the G20 nations plan for ever stronger augmentation in energy demand. Renewables enter this demand increase but not much decarbonisation is in the cards.

\section{Conclusion}

Only three measures can halt climate change, namely:

1) Immediate stop to coal and charcoal;

2) Quick replacement of oil and natural gas with solar power and wind power - see Table 1;

3) Large scale effective geo-engineering.

Table 1. Number of Ouarzazate plants for 40 per cent reduction of CO2 in some giant countries (Note: Average of 250 300 days of sunshine used for all entries except Australia, Indonesia, and Mexico, where 300 - 350 was used).

\begin{tabular}{l|l|l|l}
\hline Nation & $\begin{array}{l}\text { Co2 reduction pledge / } \\
\text { \% of 2005 emissions }\end{array}$ & $\begin{array}{l}\text { Number of gigantic solar } \\
\text { plants } \\
\text { (Ouarzazate) }\end{array}$ & $\begin{array}{l}\text { Gigantic plants needed } \\
\text { for 40 \% reduction }\end{array}$ \\
\hline United States & $26-28$ & 2100 & 3200 \\
\hline China & none & 0 & 3300 \\
\hline EU28 & $41-42$ & 2300 & 2300 \\
\hline India & none & 0 & 600 \\
\hline Japan & 26 & 460 & 700 \\
\hline Brazil & 43 & 180 & 170 \\
\hline Indonesia & 29 & 120 & 170 \\
\hline Australia & $26-28$ & 130 & 190 \\
\hline Russia & none & 0 & 940 \\
\hline Germany & 49 & 550 & 450 \\
\hline France & $37^{\mathrm{v}}$ & 210 & 220 \\
\hline Sweden & $42^{\mathrm{v}}$ & 30 & 30 \\
\hline World & N/A & N/A & 16000 \\
\hline
\end{tabular}

Note: i)The United States has pulled out of the deal; ii) No absolute target; iii) Pledge is above current level, no reduction; iv) Upper limit dependent on receiving financial support; v) EU joint pledge of $40 \%$ compared to 1990.

But the G20, responsible for more than $70 \%$ of $\mathrm{CO} 2$ emissions, seem to continue following the track in Figure 10. Renewables increase, yes, but energy supply goes faster.

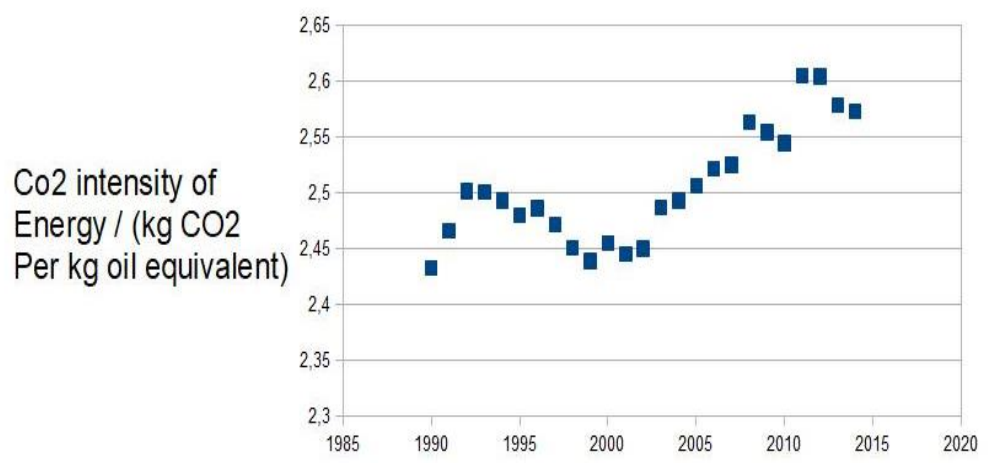

Year

Figure 10. World Co2 intensity of energy 1990-2014

Source: Carbon Dioxide Information Analysis Center, Environmental Sciences Division, Oak Ridge National Laboratory, Tennessee, United States

As economist Stern $(2007,20015)$ argues, climate policy coordination is most urgent. 


\section{References}

Dutta, P. (1999). Games and Strategies.Cambridge, MA; MIT Press

Ostrom, E. (1990). Governing the Commons. Cambridge: CUP. https://doi.org/10.1017/CBO9780511807763

Ramesh, J. (2015). Green Signals: Ecology, Growth and Democracy in India (2015). Oxford: Oxford University Press. https://doi.org/10.1093/acprof:oso/9780199457526.001.0001

Steffen, W., Rockström, J., Richardson, K., Lenton, T. M., Folke, C., Liverman, D., ... \& Donges, J. F. (2018). Trajectories of the Earth System in the Anthropocene. Proceedings of the National Academy of Sciences, 201810141.

Stern, N. (2007). The Economics of Climate Change. Oxford: OUP. https://doi.org/10.1017/CBO9780511817434

Stern, N. (2015). What are we waiting for? Cambridge, MA: MIT Press.

Sources

Paris 2015: Tracking country climate pledges. Carbon Brief, https://www.carbonbrief.org/paris-2015-tracking-country-climate-pledges

EDGAR v 4.3.2, European Commission, Joint Research Centre (JRC)/PBL Netherlands Environmental Assessment Agency. Emission Database for Global Atmospheric Research (EDGAR), release version 4.3.2. http://edgar.jrc.ec.europe.eu, 2016 forthcoming

CO2 Emission Reduction With Solar

http://www.solarmango.com/in/tools/solar-carbon-emission-reduction

BP Statistical Review of World Energy

World Bank Data Indicators

Environmental Performance Index, Yale University, https://epi.envirocenter.yale.

IEA Statistics @ OECD/IEA 2014 (http://www.iea.org/stats/inde)

\section{Copyrights}

Copyright for this article is retained by the author(s), with first publication rights granted to the journal.

This is an open-access article distributed under the terms and conditions of the Creative Commons Attribution license which permits unrestricted use, distribution, and reproduction in any medium, provided the original work is properly cited. 